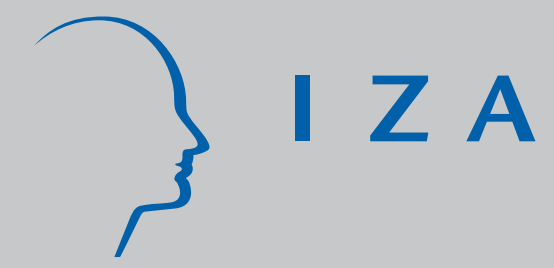

IZA DP No. 1614

Economic Performance and Unemployment: Evidence from an Emerging Economy - Turkey

Hakan Berument

Nukhet Dogan

Aysit Tansel

May 2005 


\title{
Economic Performance and Unemployment: Evidence from an Emerging Economy - Turkey
}

\author{
Hakan Berument \\ Bilkent University \\ Nukhet Dogan \\ Gazi University \\ Aysit Tansel \\ Middle East Technical University \\ and IZA Bonn \\ Discussion Paper No. 1614 \\ May 2005 \\ IZA \\ P.O. Box 7240 \\ 53072 Bonn \\ Germany \\ Phone: +49-228-3894-0 \\ Fax: +49-228-3894-180 \\ Email: iza@iza.org
}

Any opinions expressed here are those of the author(s) and not those of the institute. Research disseminated by IZA may include views on policy, but the institute itself takes no institutional policy positions.

The Institute for the Study of Labor (IZA) in Bonn is a local and virtual international research center and a place of communication between science, politics and business. IZA is an independent nonprofit company supported by Deutsche Post World Net. The center is associated with the University of Bonn and offers a stimulating research environment through its research networks, research support, and visitors and doctoral programs. IZA engages in (i) original and internationally competitive research in all fields of labor economics, (ii) development of policy concepts, and (iii) dissemination of research results and concepts to the interested public.

IZA Discussion Papers often represent preliminary work and are circulated to encourage discussion. Citation of such a paper should account for its provisional character. A revised version may be available directly from the author. 


\section{ABSTRACT \\ Economic Performance and Unemployment: Evidence from an Emerging Economy - Turkey*}

This article examines whether various macroeconomic policy shocks have different effects on overall unemployment rate and the unemployment rate by different levels of education in Turkey. These effects are assessed for total, male and female unemployment rates separately. To examine the relationship, a quarterly VAR model with a recursive order is employed to estimate the effects of real GDP, price, exchange rate, interbank interest rate, money supply and unemployment for the period from 1988:01 to 2003:04. Main findings indicate that a positive income shock reduces total unemployment while positive exchange rate and interbank interest rate innovations both increase the unemployment rate during the initial periods. The responses of high school educated unemployment rate to five macroeconomic variable shocks are different than the response of other educational unemployment rates. Furthermore, the overall results across gender are similar.

JEL Classification: E24, C32

Keywords: unemployment, economic performance and vector autoregressive regression

Corresponding author:

Aysit Tansel

Economics Department

Middle East Technical University

Ankara 06531

Turkey

Email: atansel@metu.edu.tr

\footnotetext{
* The authors gratefully acknowledge the Financial Support from the Turkish Academy of Science (SBB-4024).
} 


\section{Introduction}

This article examines whether various macroeconomic policy instruments have different effects on overall unemployment rate and the unemployment rate by different levels of education. These effects are assessed for male and female unemployment rates separately as well as for the total. The focus is on the unemployment rate by education levels. Bulutay (1996) argues that unemployment rates across different education levels have different characteristics. For example after the February 2001 crisis, unemployment rate was 13.31 percent for high school graduates while it was 4.08 percent for the literate without diploma. Moreover the unemployment rate for high school graduate females was 20 percent while for males 11.47 percent. The unemployment rate for the literate without diploma was 1.53 percent for females and 7.16 percent for males. In the analysis that follows we compare how various shocks affect the female and male unemployment rates as well as the overall unemployment rate. The overall unemployment rate reflects the labor market conditions for the entire labor force. Since the labor force participation of males is much higher than that of the females, the movements in the male and overall unemployment rates are expected to be similar to each other.

In this study, the specific exogenous changes whose effects on unemployment are assessed include changes in output, exchange rate, prices, interest rate and other macroeconomic factors. Using econometric techniques, Vector Autoregression (VAR) specifications are estimated for the effects of changes in various macroeconomic factors on the overall unemployment rate and unemployment rates by education levels. These effects are estimated for the period 1988:01 to 2003:04.

In the literature only a handful of studies have been done to investigate the role of fundamental macroeconomic variables on the unemployment rate. To the best of our knowledge, there are two theoretical studies. These are by Agenor and Aizenman (1999) and Daitoh (2003). Agenor and Aizenman (1999) theoretically analyzed the implications of fiscal and labor market policies on output, wages and unemployment in a general equilibrium model for a small open developing economy. They found that there is no close relationship in the short run between changes in output and the unemployment rate. Daitoh (2003) theoretically investigated how the low interest rate policy in the commercial banking sector affects the urban unemployment in a small open Harris-Todaro model. His results suggested that in a Harris-Todaro economy where the agriculture plays a dominant role in the domestic employment and production, the financial liberalization aggravates the rate and volume of urban unemployment. The papers most similar to ours are by Zavodny and Zha (2000) and 
Algan (2002). Zavodny and Zha (2000) examined the relationship between monetary policy and race-specific unemployment rate in the US and concluded that black unemployment rate does respond slightly differently than the overall unemployment rate to macroeconomic variables. Algan (2002) examined the response of unemployment to aggregate demand, aggregate supply shocks using a structural VAR model for France and the US. He observed that the aggregate demand, aggregate supply framework is well suited for the US but poorly explains the French labor market. Our study assesses the effects of various macroeconomic shocks (beside the aggregate demand and supply shocks) on the various components of unemployment rate. The present study is the first application to Turkish data of examining the relation between macroeconomic policy instruments and the unemployment rate. There are various advantages of using Turkish data. First, Turkey is one of the predominant emerging markets. Second, Turkish financial and labor markets are not heavily regulated and Turkish real wages are flexible. Therefore, economic shocks are transmitted to labor markets easily. Third, high variability of the Turkish economic variables decreases the Type-II error - the error that is made when an incorrect null hypothesis is not rejected. Main findings of this paper indicate that a positive income shock reduces total unemployment while a positive exchange rate and interbank interest rate innovations both increase the unemployment rate during the initial periods. Furthermore, the results show that the responses of the female and male unemployment rates to the five economic shocks are mostly similar across different educational levels except for the high school level.

This paper is organized as follows. The next section analyzes the trends in the overall unemployment rate and the unemployment rates by education levels for males and females, in Turkey. The data used in this study are described in Section 3. The econometric model used to estimate the relationship between various macroeconomic factors and the unemployment rate is explained in Section 4. The estimation results are discussed in Section 5. Conclusions appear in Section 6.

\section{Trends in Unemployment Rates}

We first give a brief account of the recent developments in the Turkish economy for the period 1988 to 2003. Figure 1 plots the GDP per capita in USD. During this period, there were four major shocks in the Turkish economy. The first one was in 1991 and was due to the adverse effects of the Gulf War. The second major shock occurred in 1994 due to the mismanagement of the domestic debt. A stabilization policy was put into effect in April. Interest rate and the exchange rates soared. There was a devaluation of the Turkish lira by 
almost 70 percent. The economy contracted by about six percent. However, the recovery was quick and in the following year the growth rate was eight percent. The third major shock was in 1999. During the first half of the 1999 the delayed effect of the Russian crisis on the Turkish economy was felt. In the second half of the 1999 two major earthquakes struck the eastern Marmara region which is the industrial heartland of the country with substantial adverse effects on output and employment. Fourth major shock was the financial crisis of November 2000 followed by the February 2001 crisis. This was the severest shock in the history of the Turkish Republic. The GNP declined by about 9.6 percent in 2001. The effects of this crisis were both prolonged and widespread as compared to the previous crises.

In order to visualize the evolution of the unemployment we plot the rates by gender over the 1988-2003 period in Figure 2.According to the State Institute of Statistics of Turkey (SIS), unemployed are defined as all persons 15 years of age and over who are not employed during the reference period, who have taken specific step(s) to obtain a job during the last six months and are available to start work within 15 days (See SIS, 2004). The figure shows the biannual rates before the 2000 and the quarterly rates for the 2000 and after due to data availability. It is believed that the unemployment rate should follow the trends in the economy. However, it is not possible to see the impact of the major shocks on the unemployment rate with the biannual data. In contrast the quarterly rates reflect the effects of the 2001 crisis and the ensuing recession.

Figure 2 shows that the total unemployment rate follows the trends in the male unemployment rate. However, female unemployment rate shows fluctuations over time although following the same trend. There is some increase in the male unemployment rate in 1994 and then in 1999, but the increasing trend is evident after 2000 due to the effect of 2001 crisis and the recession that followed.

Unemployment rates by education levels are shown in Figure 3 for females and in Figure 4 for males. Figure 3 shows that, unemployment rate of the university graduates for females are above the average unemployment rate. Another observation is that the unemployment rates of the junior high school and vocational high school graduates are more cyclical than the unemployment rate of the other education levels. Figure 4 indicates that for the period between 1994 and 1997 male unemployment rates showed a steady decrease in all education levels. However, after the 2001 recession, male unemployment rate increased substantially for all education levels. These figures indicate that unemployment rate of high school graduates are higher than that of the other education levels for both males and females. Further the unemployment rates of university graduates increased sharply after the 2001 
crisis. As it is well known even, the graduates of the prestigious universities were adversely affected, by the crisis.

\section{Data}

Quarterly data from 1988:01 to 2003:04 are used in this study. Macroeconomic indicators are real $\mathrm{GDP}(\mathrm{Y})$, price $(\mathrm{P})$, exchange rate $(\mathrm{EXCH})$, interbank interest rate (INTERBANK) and money supply (M1) plus repo (M). They are obtained from electronic database system of Central Bank of the Republic of Turkey (CBRT), (CBRT, 2004). The other data set which includes the total unemployment rates and the unemployment rates by education and gender were compiled from data delivery system to the State Institute of Statistics Prime Ministry Republic of Turkey (SIS, 2004). During the period 1988-1999, The Household Labor Force Surveys (HLFS) were conducted twice a year in April and October. In the year 2000, application frequency, sample size, estimation dimension, questionnaire design and some other aspects of the HLFS were changed. Since 2000, the households have been followed quarterly. Since we didn't have quarterly data for the 1988-1999 periods, we estimated the missing quarters by using the interpolation method.

\section{Model Specification}

A quarterly VAR model is used to estimate real GDP, price, exchange rate, interbank interest rate, money supply and the unemployment relationship for the period from 1988:01 to 2003:04. Real GDP is used as a measure of income. Price level is measured by the GDP deflator. The Exchange rate is defined as Turkish Lira value of the official currency basket which is composed of 1 USD and 0.77 Euro. Interest rate is interbank's overnight interest rate. Finally, M1+repo are taken as the measure of money supply. There are two reasons for including repo in the money supply aggregates (Berument, 2004). First, most of the repo transactions were overnight, hence this money aggregate was liquid. Second, agents prefer to repo their savings rather than open deposit accounts since the repo rates are considerably higher.

In order to address the seasonality, seasonal dummies are included in the VAR as exogenous variables. For the three domestic financial crises in April 1994, November 2000 and February 2001 three exogenous dummy variables are also included. The coefficients on the dummy variables for the 1991 and 1999 shocks to the economy were not statistically significant and therefore, excluded from further analysis. Finally, because of the change in the 
definition of M1 and repo, one more dummy variable is included in the VAR model after 1996.

The order of the variables in the VAR system is important. Ordering should imply that first variable affects all the remaining variables contemporaneously, but others affect it with a lag. Our variables are ordered as real GDP, price, exchange rate, interbank interest rate, M1+repo and unemployment. It is assumed that GDP affects all the remaining variables contemporaneously, but others affect it with a lag, but not contemporaneously. For example, when exchange rate is the monetary policy variable, it is further assumed that monetary policy actions have contemporaneous effects on interbank interest rate, M1+repo and unemployment. Similar assumptions were made by Christiano, Eichenbaum and Evans (1999) and Berument (2004). The model was estimated using log levels for all data except the interbank interest rate. The lag length of two for the VARs was determined by the Schwartz Bayesian selection criterion.

\section{Empirical Evidence}

Figures 5 to 12 report the impulse responses of the core VAR model that include real GDP, price, exchange rate, interbank interest rate, M1 plus repo and unemployment by educational statuses with two lags for 20 periods. The error bands for the impulse responses are drawn at the $90 \%$ levels of confidence. The standard errors are calculated by bootstrapping with 3000 draws.

Figure 5 plots how one standard deviation shock given to five macroeconomic variables as well as the unemployment rates themselves affect the behavior of unemployment. For expositional purposes, first we will interpret how the unemployment changes with income innovations. The upper left one, in Figure 5A, B and $\mathrm{C}$ show how one standard deviation shock to income decreases the total, female and male unemployment for the whole period. All responses are statistically significant except for the initial periods for the total, female and male, as well as the second quarter for the female. This result is consistent with various econometric studies such as by Algan (2002) who finds that a positive demand shock decreases the unemployment rate permanently for France and the US. However this effect is not statistically significant at the $10 \%$ level for France. Similarly, Zavodny and Zha (2000) find that tight monetary policies (negative demand shock) increase the unemployment. Hence, our results are parallel with the results of these two studies.

Next we elaborate on how unemployment is affected by income innovations across the education levels. We consider Illiterate, Literate without any Diploma, Primary School, 
Junior High School, Vocational High School, High School and Higher Education classifications. In order to save space, we will elaborate only the statistically significant estimates.

In Figures 6.A and $\mathrm{C}$, the responses of total and male illiterate to positive income innovation are negative and statistically significant, except for the response between 2 and 3 periods. Figure 6.B suggests that female illiterate has a negative impact after first quarter. However, after 3-periods, responses are statistically significant. Figures 7.A, B and C show that one standard deviation shock to income decreases total, female and male unemployment of literate without any diploma for the whole period. However, the first three quarters and after 9-periods, one standard deviation shock to income decreases the total unemployment, and this effect is statistically significant. For females, the effects are statistically significant for initial levels and after the $7^{\text {th }}$ period. Finally for the males, only the period between 2 and 3 is statistically significant.

Figures 8.A, B and C report response of Primary School Unemployment to income innovation for the total, female and male unemployment. These three types of unemployment decrease for the whole period. Figures 9.A and C, show that one standard shock to income increases total and male junior high school unemployment at the initial level but decrease them for the rest of the periods. They are statistically significant after $7^{\text {th }}$ period. However, the female junior high school unemployment responses are negative for the whole period and statistically significant after the tenth quarter. In Figures 10.A and C, the responses of total and male vocational high school unemployment are negative. The effects between the $1^{\text {st }}$ and $3^{\text {rd }}$ as well as after the $10^{\text {th }}$ periods are statistically significant.

Figure 11 reports the analysis for the high school unemployment. One standard deviation shock to income increases total, female and male high school unemployment for the all periods. However, only the total and male high school unemployment effects are statistically significant at the initial level. Figures 12.A, B and C show that one standard deviation shock to income decreases total, female and male higher education unemployment after around 9 quarters and the effects are statistically significant. In sum, the general trend is that a shock on the income decreases the unemployment of different educational levels except the high school unemployment, which is statistically significant only at the initial level.

Turkey is a small open economy. It mostly imports raw materials, intermediate products, and machine \& equipment for its investment. Therefore, it is plausible that exchange rate movements affect the state of the economy adversely and increases unemployment. Exchange rate also affects the economic performance through the net exports. 
Higher exchange rate encourages exports and discourages imports (see Berument and Pasaogullari, 2003, on the discussion of the effect of depreciation on the Turkish economic performance). Therefore, next we assess how unemployment by various levels of education responds to the exchange rate innovations.

Figures 5.A, B and $\mathrm{C}$ show that one standard deviation shock to exchange rate increases the total, female and male unemployment for 8, 10 and 6 quarters respectively. After that they are affected negatively. However, none of them are statistically significant. In Figures 6 to 12, first row of second column reports the response of unemployment by different educational levels to the exchange rate innovation. Most of the education levels have positive impact for the first periods. After that they have negative impact. However, the confidence intervals clearly indicate that the effects of shocks on the unemployment are not statistically significant.

We next assess the impact of changes in money on total unemployment and unemployment by different educational levels and gender. The one standard deviation shock to the money causes the unemployment to decrease but only changes in total and male unemployment are statistically significant at the initial level. Money shocks drive up unemployment for the literate without diploma while unemployment rates for the other education levels are moved in the opposite direction. These decreases are statistically significant at the initial level for unemployment of junior high school, high school and higher education levels.

A shock on the price has a negative and significant effect on total unemployment and unemployment by different educational levels after about 3 periods except for the high school unemployment. The responses of the high school unemployment are positive and statistically significant for the total and male unemployment after 9 periods, for the female unemployment after 5 periods.

After examining the one standard deviation shock to the price, we will interpret the innovation to the interbank interest rate. Positive interbank interest rate innovations are often taken as an indicator of monetary policy (Christiano et al., 1999). One standard deviation shock to the interbank interest rate increases the total unemployment for 11 quarters but only the first quarter of the increase in total unemployment is statistically significant. Figure 5.B reports the results for female unemployment. The increase in unemployment is observed for the first quarter, but the evidence is not statistically significant. Figure 5.A and C show effect of one standard deviation shock to interbank interest rate on total and male unemployment. 
Both of the unemployment increase for eight quarters but the increases are statistically significant for the first quarter only.

Figure 6.A shows that the response of total illiterate unemployment to interbank innovations is positive for the first quarter. After one period the response falls below zero for the rest of the 20-periods. However it is statistically significant only for the period between 2 and 3. Figure 7.B shows that an initial response of female unemployment for literate without diploma to one standard error shock to interbank interest rate is positive. Then the response turns out to be negative for the rest of the periods. However, it is statistically significant only for the periods between 2 and 3. Figures 8 and 10 report that one standard deviation shock to interbank interest rate increases unemployment for Primary School and Vocational High School graduate males as well as the total. These increases are statistically significant at the initial levels. For the remaining categories, the impulse responses do not reveal any statistically significant effect of an interbank interest rate innovation on unemployment.

Finally, we will interpret of the response of the total unemployment and the unemployment by various educational levels to their own shock. Figures 5.A, B and C show that the initial response of unemployment to its own shock is strongly positive after approximately 2 periods then the unemployment declines sharply. Total and male unemployment responses are statistically significant at the initial levels and after 9 periods but for female unemployment it is significant just for the initial period. The responses of educational levels of the unemployment to their own shocks are positive for the total, female and male unemployment. These increases are statistically significant for most of remaining unemployment categories across gender and education levels.

We conclude that total, female and male unemployment responses to five economic shocks are mostly similar across different educational levels except for the high school level.

\section{Discussion}

Overall, female and male unemployment respond to economic shocks similarly. Moreover, the directions of most of the unemployment classifications to economic shocks are similar across different education levels. However, when we compare unemployment education classifications, response of the High School Unemployment to five macro economic shocks are different from other educational levels. It is important to recognize that high school unemployment is around $20 \%$ of the total unemployment. Therefore this effect is important. 
It is also important to recognize that shocks to interbank interest rates and money do not have a long-run effect on any type of unemployment. However, the Total Unemployment responds to these two variables in the short run. Exchange rate does not have statistically significant effect on any class of unemployment in any horizon but it affects total and female High School Unemployment. The effect of exchange rate on total and female Total Unemployment exists only for the first period. The Central Bank of the Republic of Turkey used these three variables as policy tools in the past. Since none of these variables do have statistically significant effects on unemployment in the long-run, this clearly suggests the ineffectiveness of the monetary policy in the long-run. However, in the short-run, the effect is limited. Therefore, this study suggests that the policies of the Turkish Central Bank are not responsible for the high level of unemployment experienced.

On the other hand, income, prices and unemployment shocks themselves have persistent effect on unemployment. Positive income and prices shocks decrease unemployment across all categories except the High School Unemployment. Male and female High School Unemployment increase with positive income and price shocks. It is important to recognize that income and price shocks affect all unemployment variables in the same directions. This may suggests that not the supply but demand side shocks were the main determinants of unemployment in the past. Moreover, shocks to unemployment, most of the times, have a persistent effect. This supports the hysterisis argument - unemployed will have less chance to be employed in the future due to marketability.

In conclusion, we can say that the demand policies rather than the monetary policy as well as the unemployment itself are the main factors that explain the behavior of unemployment. This may suggest that policy makers should use not monetary but demand policies as well as the labor market regulations to hamper the unemployment.

\section{Conclusion}

This study examines whether exogenous shifts in income and monetary policy have different effects on overall unemployment rate and the unemployment rate by different levels of education by gender in Turkey. In order to investigate the relationship between macroeconomic variables and unemployment, the VAR method is applied for the 1988-2003 period using quarterly data.

The empirical evidence suggests that positive income shock decreases total unemployment. This finding is consistent with Algan (2002) and Zavodny and Zha (2000).

We further find that positive income shock decreases the total unemployment and the 
unemployment by different levels of education except the unemployment at the high school level. Unemployment at the high school level which is statistically significant at the initial levels is found to increase with a positive income shock. With regards to the exchange rate innovations the results indicate that unemployment rate increases during the initial periods after which unemployment rate decreases. A positive innovation in the money indicates that unemployment for junior high school, high school and higher education levels have negative effects and statistically significant at the initial levels. Next, one standard deviation shock to the price decreases the unemployment of different educational levels after about 3 periods and they are statistically significant. The results further suggest that a positive innovation in the interbank interest rates increase the unemployment rate unambiguously during the initial periods. Further unemployment rates at different levels of education increase also.

Macroeconomic variable effects on overall unemployment rate and the unemployment rates by different levels of education are also assessed for the total, male and female unemployment rates separately. The model used indicates that total, female and male unemployment responses to five economic shocks are mostly similar across different educational levels except for the high school level.

Lastly, shocks to interbank interest rates and money do not have a long-run effect on any type of unemployment; only the Total Unemployment responds to these two variables in the short run. On the other hand, income, prices and unemployment shocks themselves have persistent effect on unemployment. 


\section{References}

Agenor Pierre R. and J. Aizenman, 1999, "Macroeconomic Adjustment with Segmented Labor Markets”, Journal of Development Economics, 58, 277-296.

Algan, Yann, 2002, "How Well Does the Aggregate Demand-Aggregate Supply Framework Explain Unemployment Fluctuations? A France-United States Comparison", Economic Modelling, 19, 153-177.

Berument Hakan, 2004, "Measuring Monetary Policy for a Small Open Economy",mimeo, Department of Economics, Bilkent University, Ankara.

Berument, Hakan and Mehmet Pasaogullari, 2003, "Effects of the Real Exchange Rate on Output and Inflation: Evidence from Turkey", Developing Economies, 41(4), 401-435.

Bulutay, Tuncer, 1996, Education and the Labour Market in Turkey: Proceedings of a Seminar Held in Ankara, State Institute of Statistics, Ankara.

Central Bank of the Republic of Turkey, 2004, http://www.tcmb.gov.tr (10.03.2004)

Christiano, L., M. Eichenbaum, and C. Evans, 1999, "Monetary Policy Shocks: What Have We Learned and to What End?", Handbook of Macroeconomics, Volume 1a, Chapter 2 ed. Michael Woodford and John Taylor, North Holland.

Daitoh, Ichiroh, 2003, "Financial Liberalization, Urban Unemployment and Welfare: Some implications of the Artificial Low Interest Rate and the High Wage Rate Policies in LDCs", Journal of Development Economics, 72, 163-179.

State Institute of Statistics, 2004, http://www.die.gov.tr (10.03.2004)

Zavodny M. and T. Zha, 2000, "Monetary Policy and Racial Unemployment Rates", Federal Reserve Bank of Atlanta, Economic Review, Fourth Quarter, Volume 85, Number 4, 1-16. 
Figure 1: GNP per Capita (In USD)

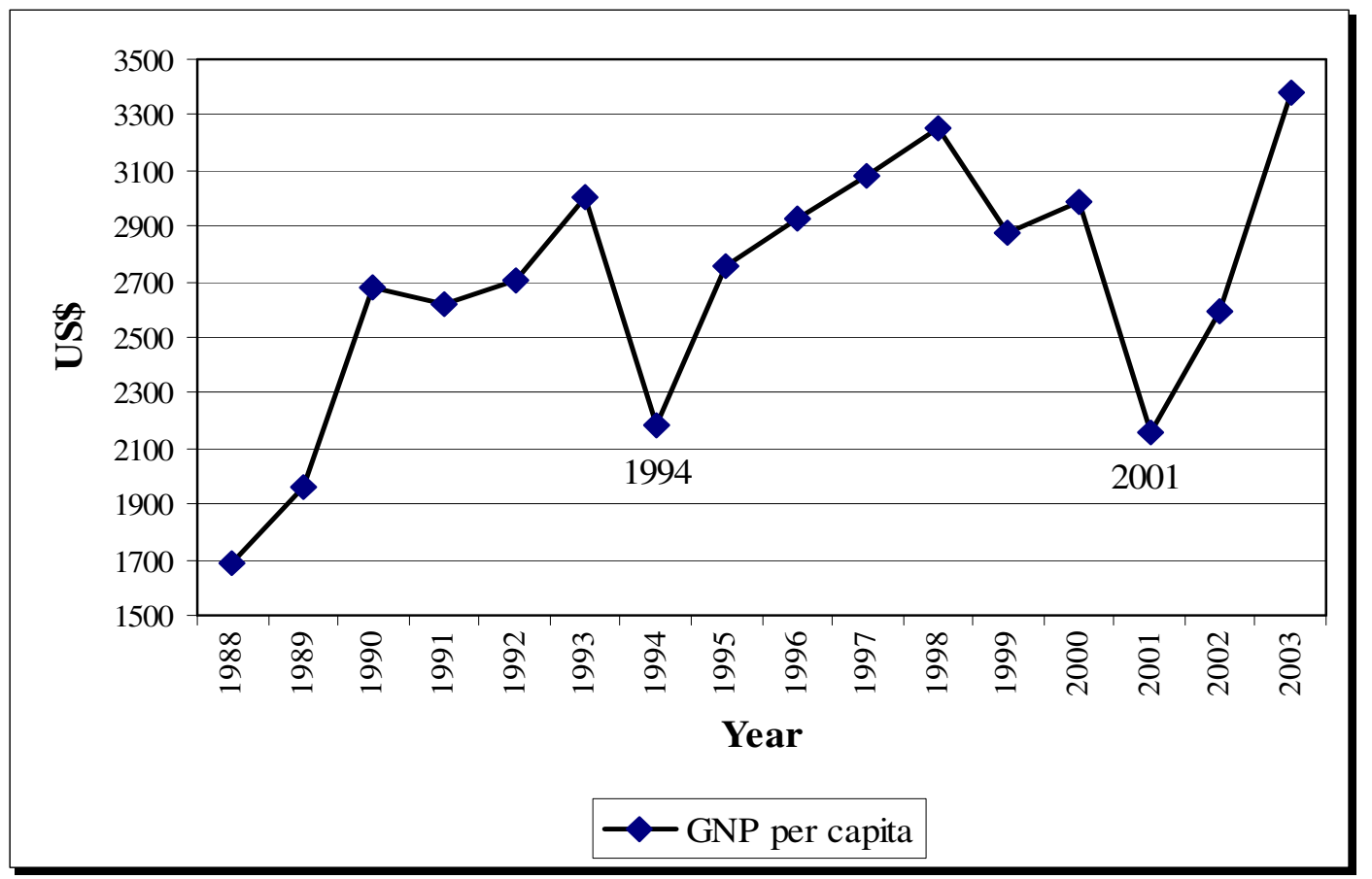

Figure 2: Unemployment Rate by Gender

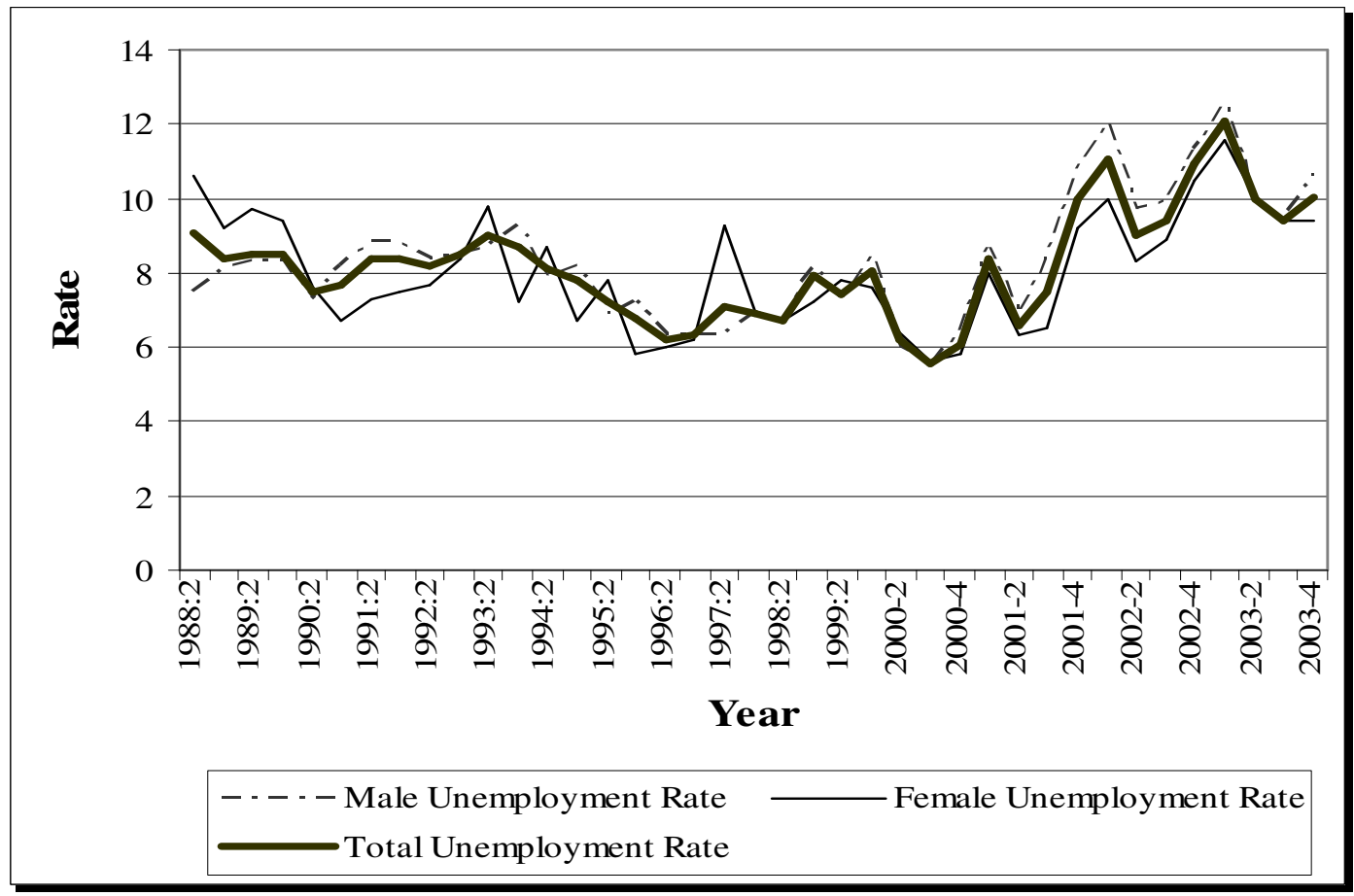


Figure 3: Female Unemployment Rate by Educational Level

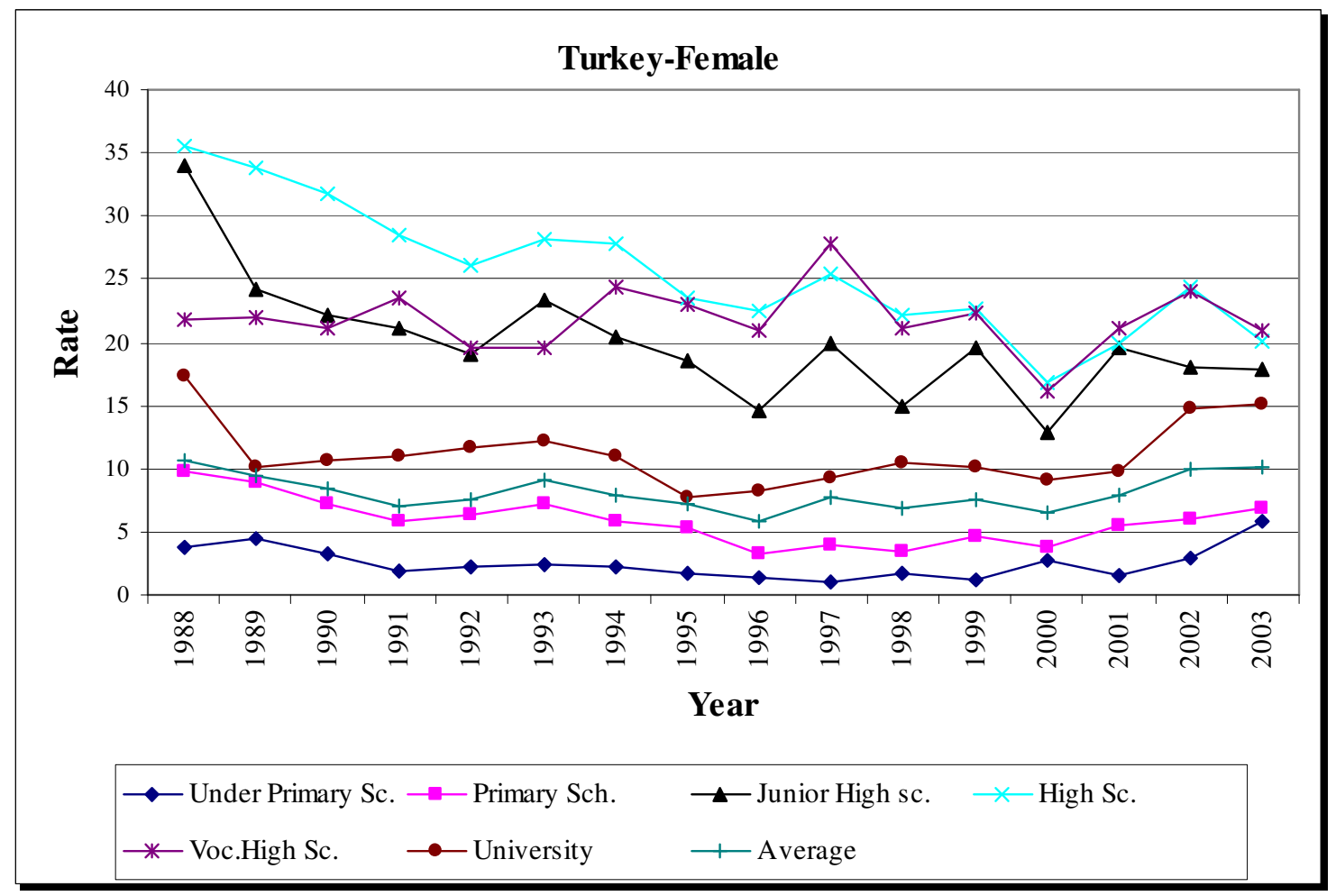

Notes: Under Primary School includes the illiterates plus the literate without diploma.

Figure 4: Male Unemployment Rate by Educational Level

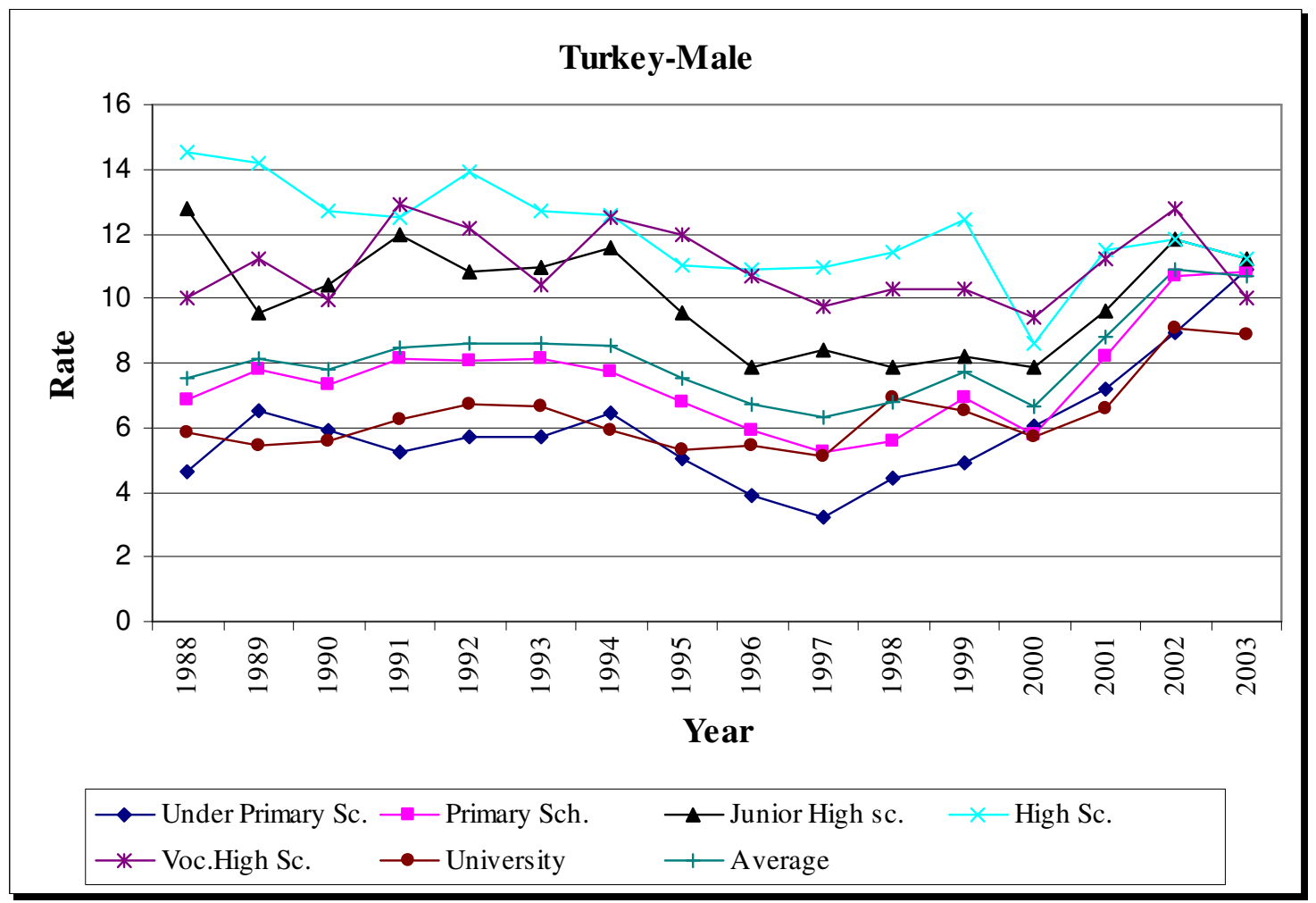


Figure 5: Responses of Unemployment to Economic Shocks A: On Total Unemployment

Effects of Shocks on Unemployment
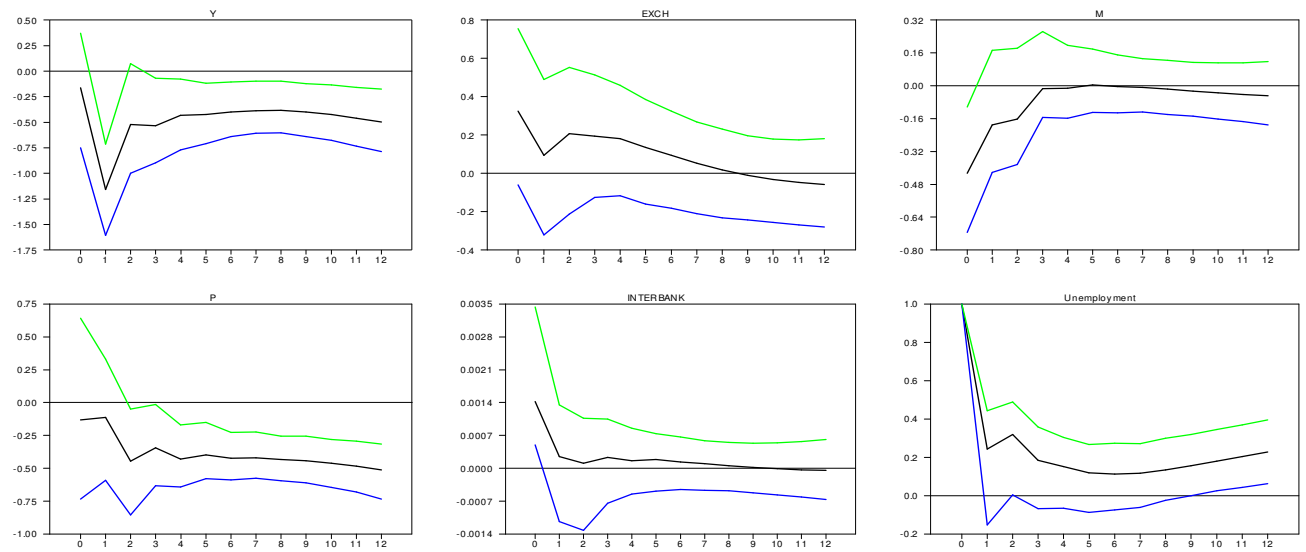

B: On Female Unemployment

Effects of Shocks on Unemployment_f
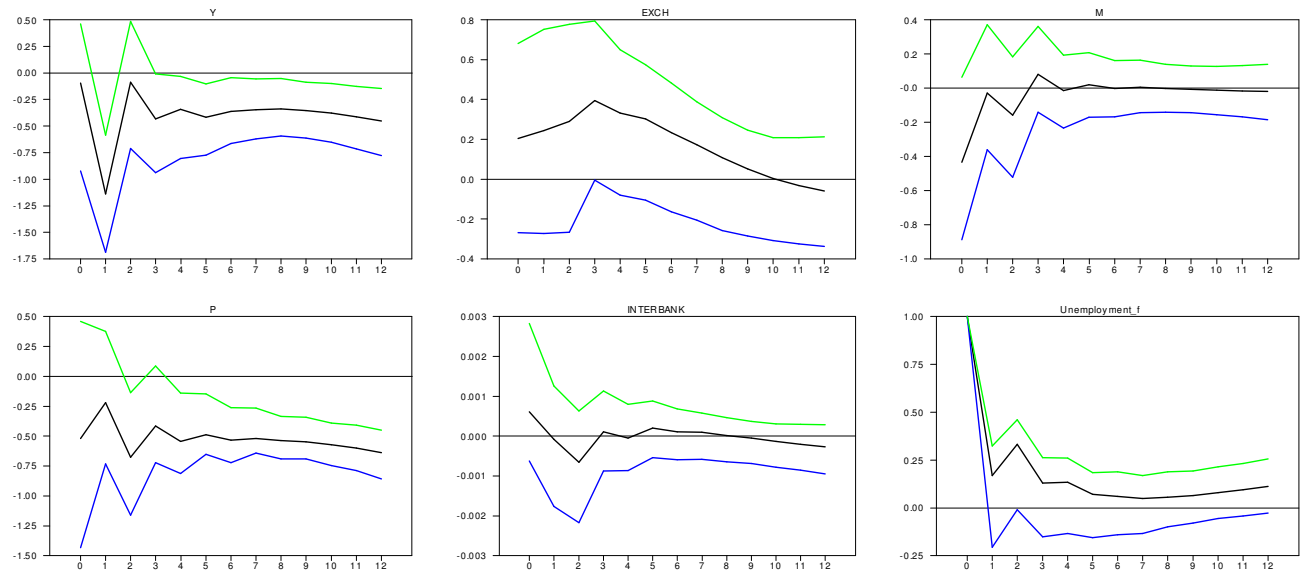

\section{C: On Male Unemployment}

Effects of Shocks on Unemployment_m
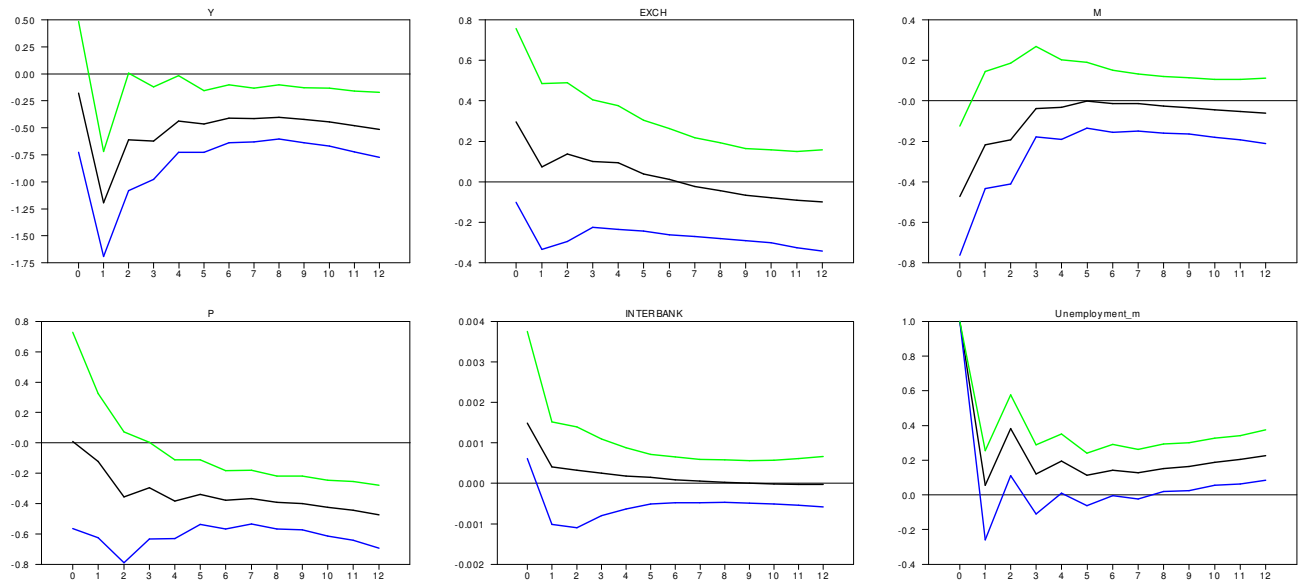
Figure 6: Responses of Illiterate Unemployment to Economic Shocks A: On Total Illiterate Unemployment

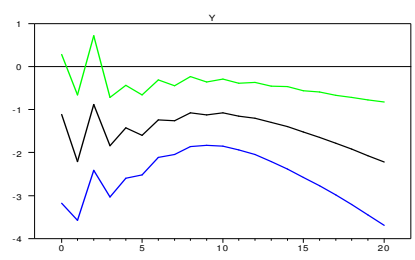

Effects of Shocks on Illiterate_t
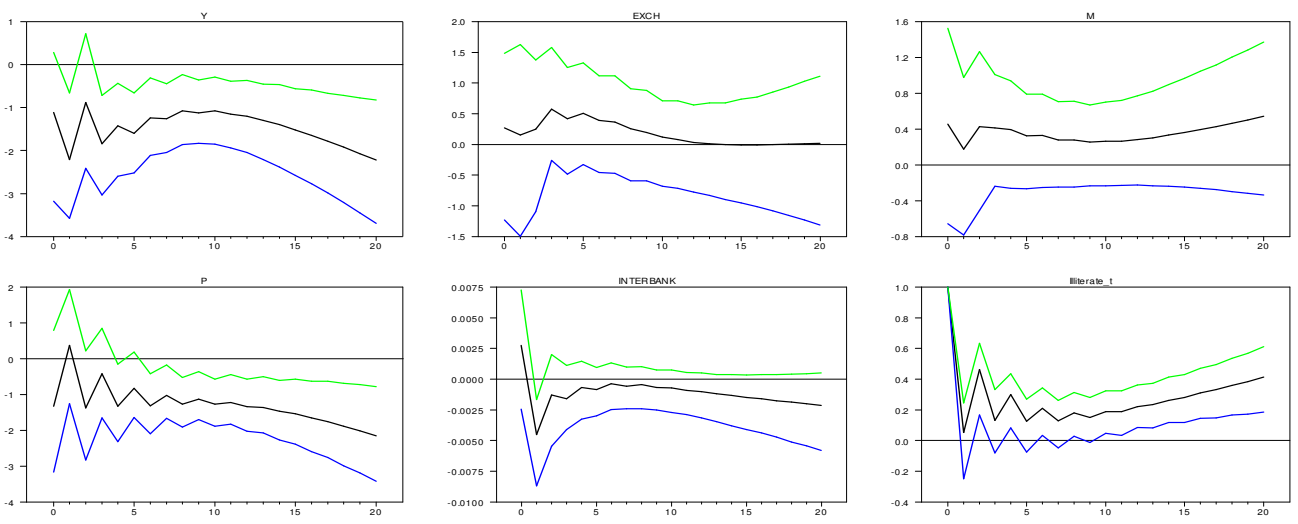

\section{B: On Female Illiterate Unemployment}

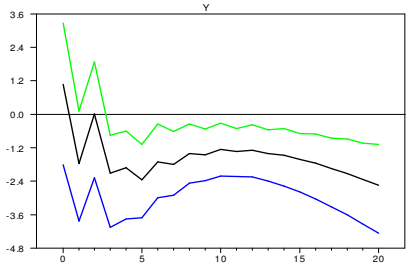

Effects of Shocks on Illiterate
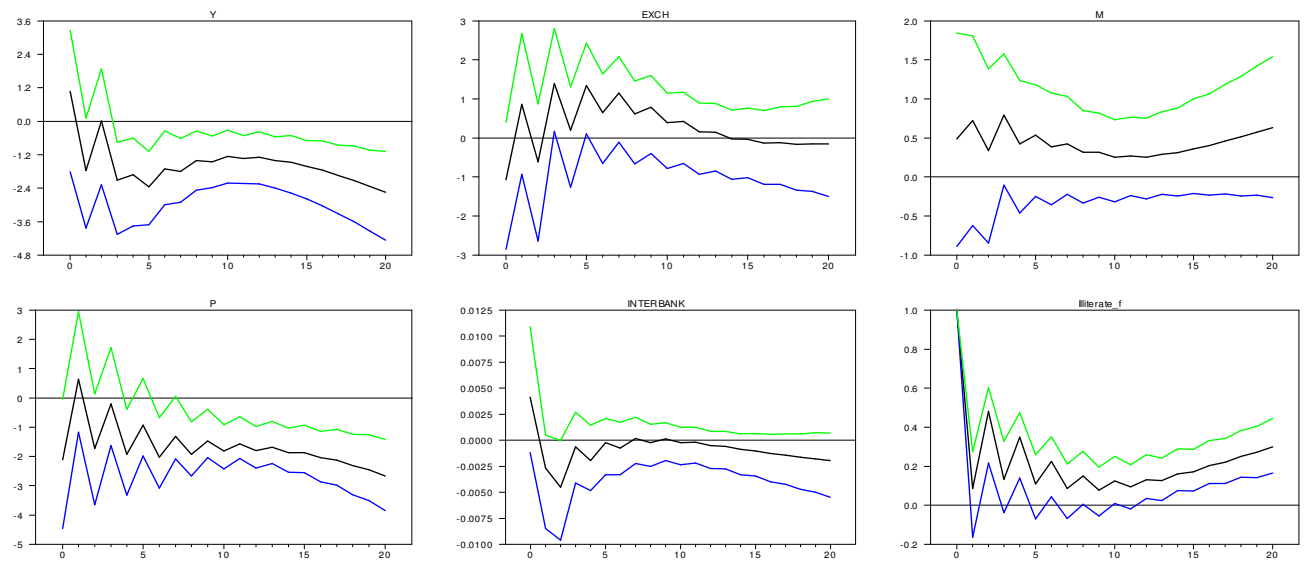

\section{C: On Male Illiterate Unemployment}

Effects of Shocks on Illiterate_m
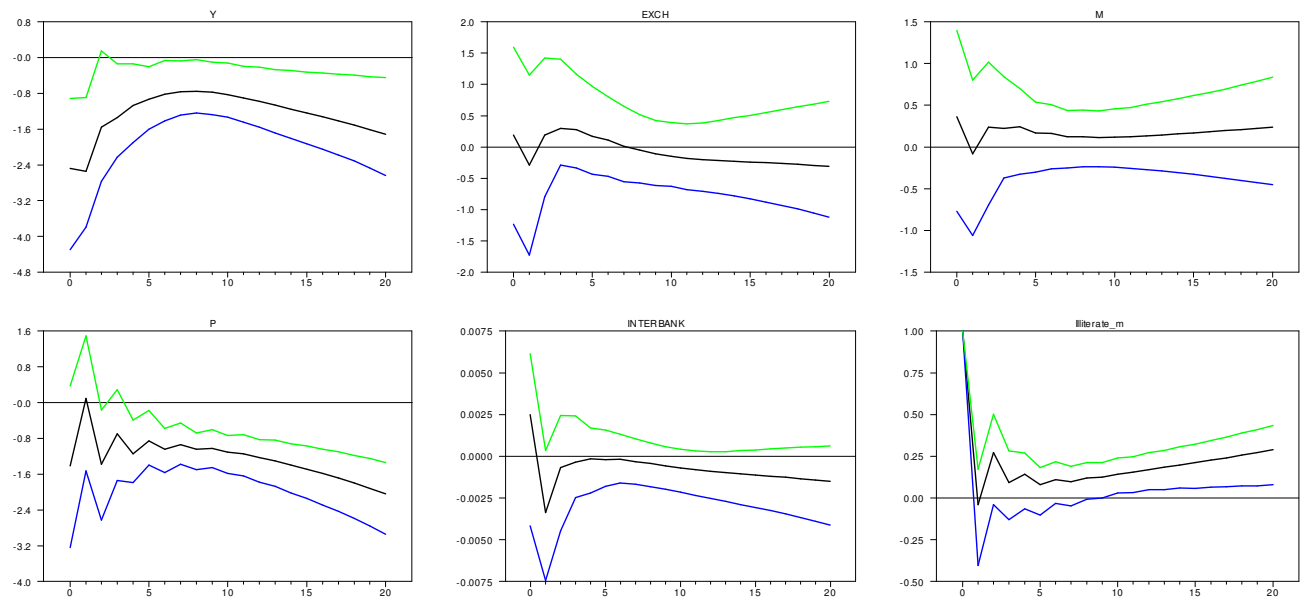
Figure 7: Responses of Literate without any Diploma Unemployment to Economic Shocks A: On Total Literate without any Diploma Unemployment

Effects of Shocks on Literate wdip_t
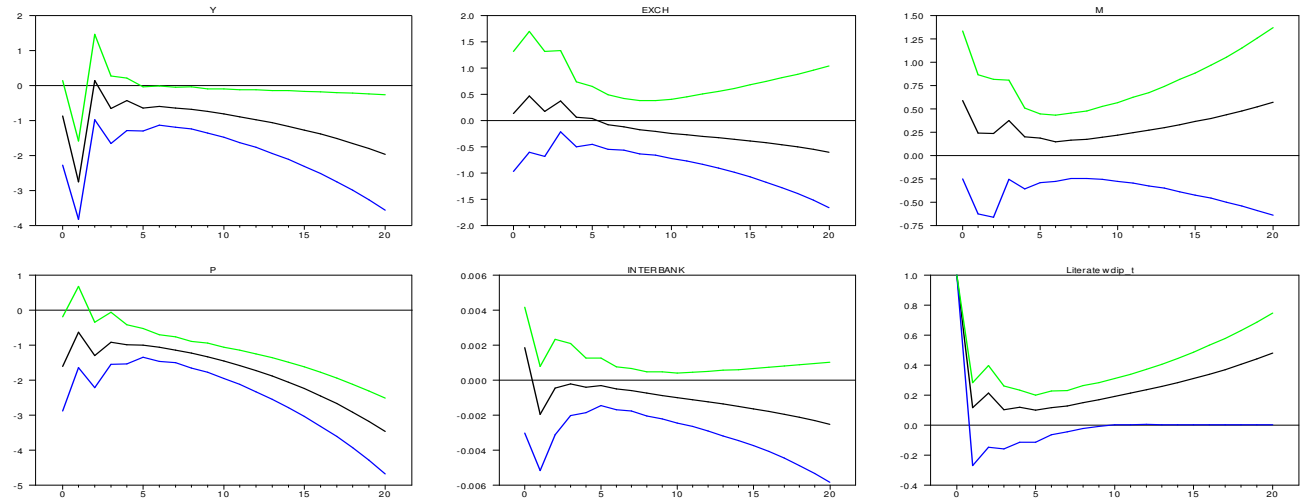

B: On Female Literate without any Diploma Unemployment

Effects of Shocks on Literate wdip_f
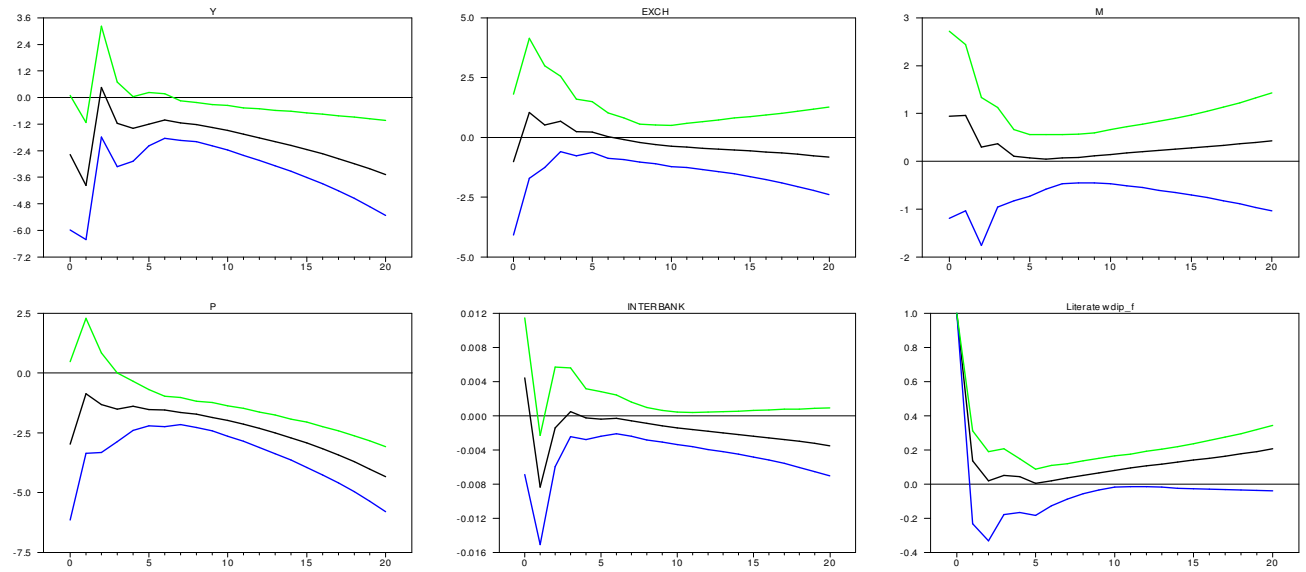

C: On Male Literate without any Diploma Unemployment

Effects of Shocks on Literate wdip_m
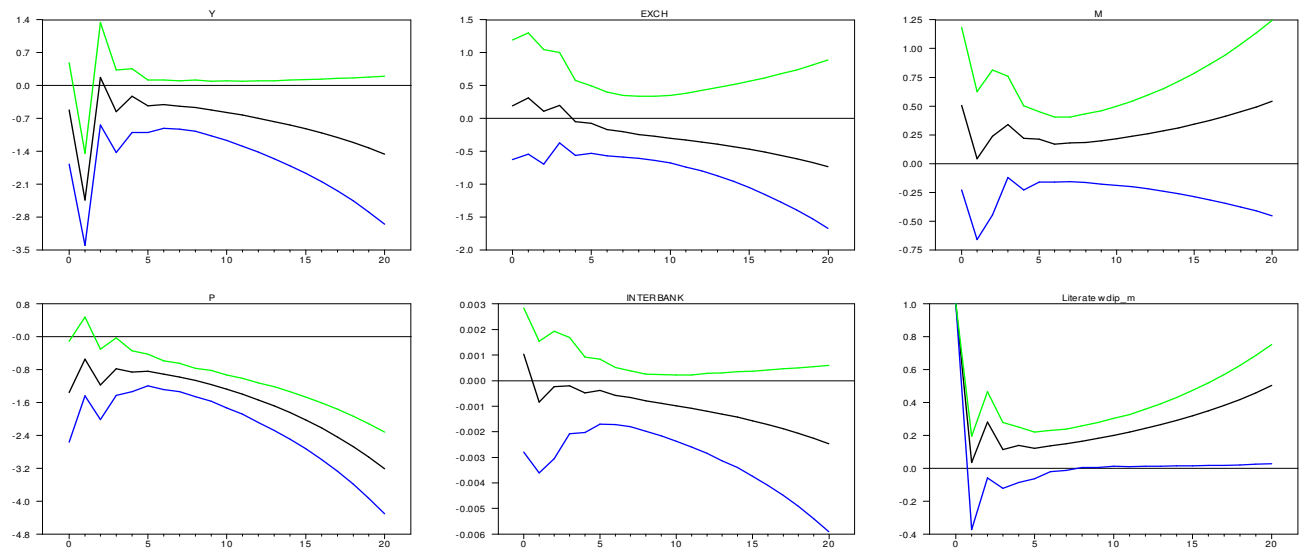
Figure 8: Responses of Primary School Unemployment to Economic Shocks A: On Total Primary School Unemployment

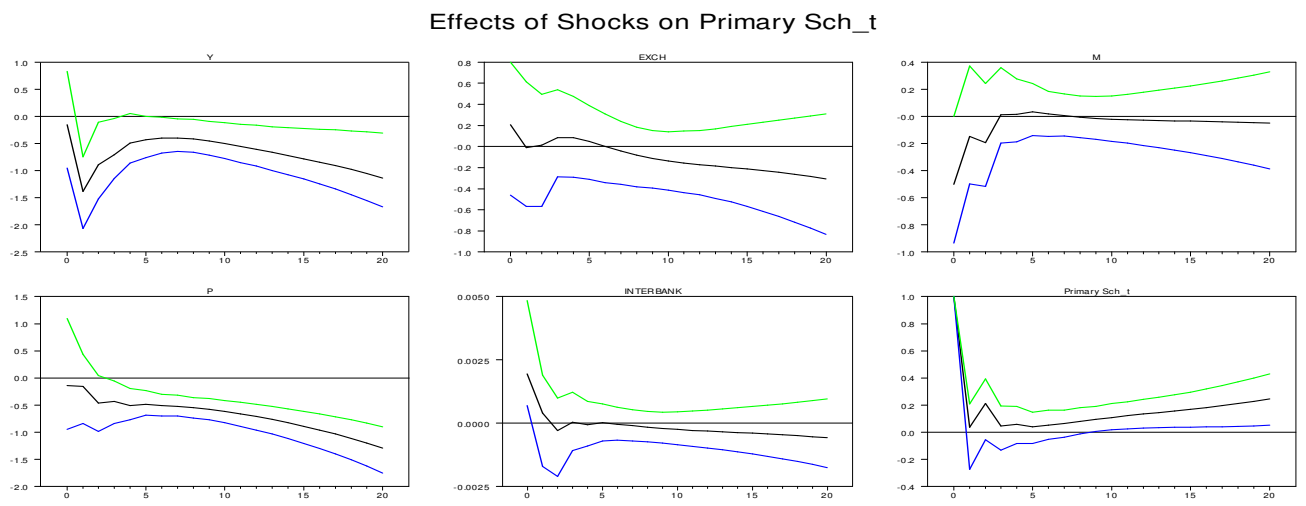

\section{B: On Female Primary School Unemployment}

Effects of Shocks on Prifary Sch_f
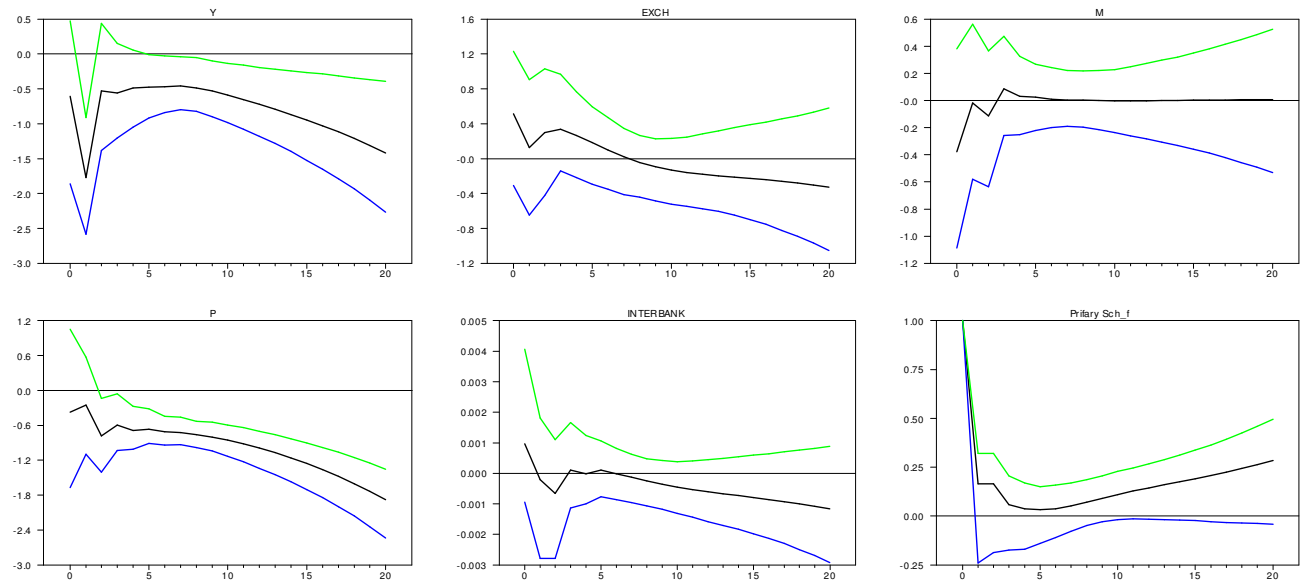

\section{C: On Male Primary School Unemployment}

Effects of Shocks on Primary Sch_m
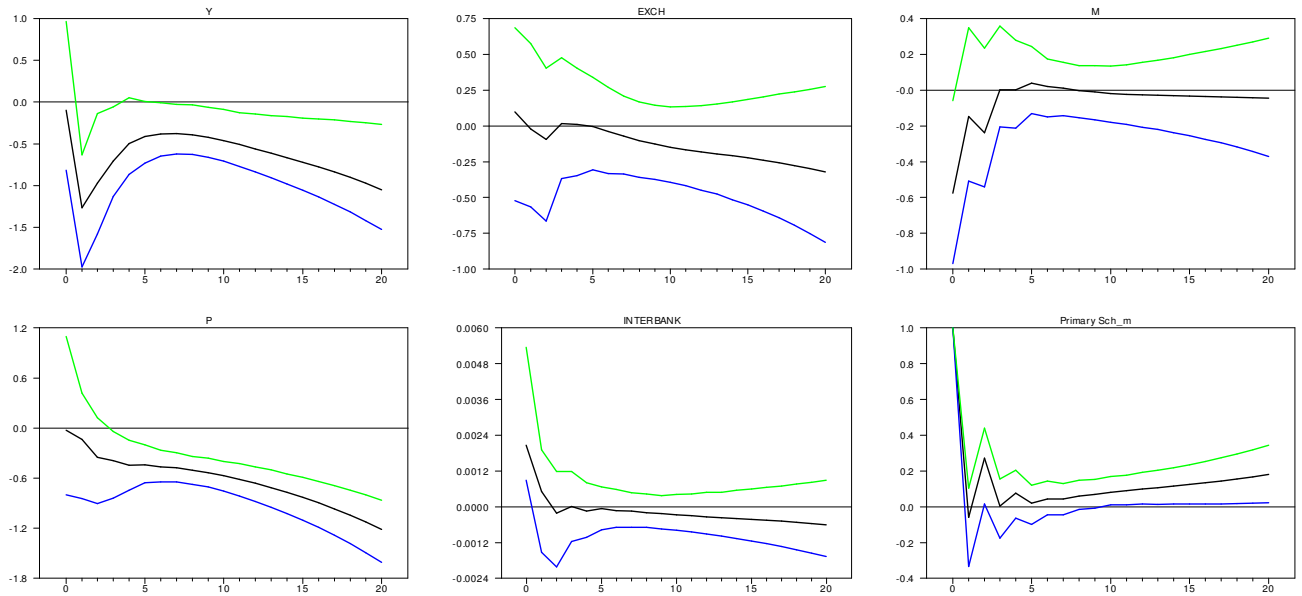
Figure 9: Responses of Junior High School Unemployment to Economic Shocks A: On Total Junior High School Unemployment

Effects of Shocks on Junior HS_t
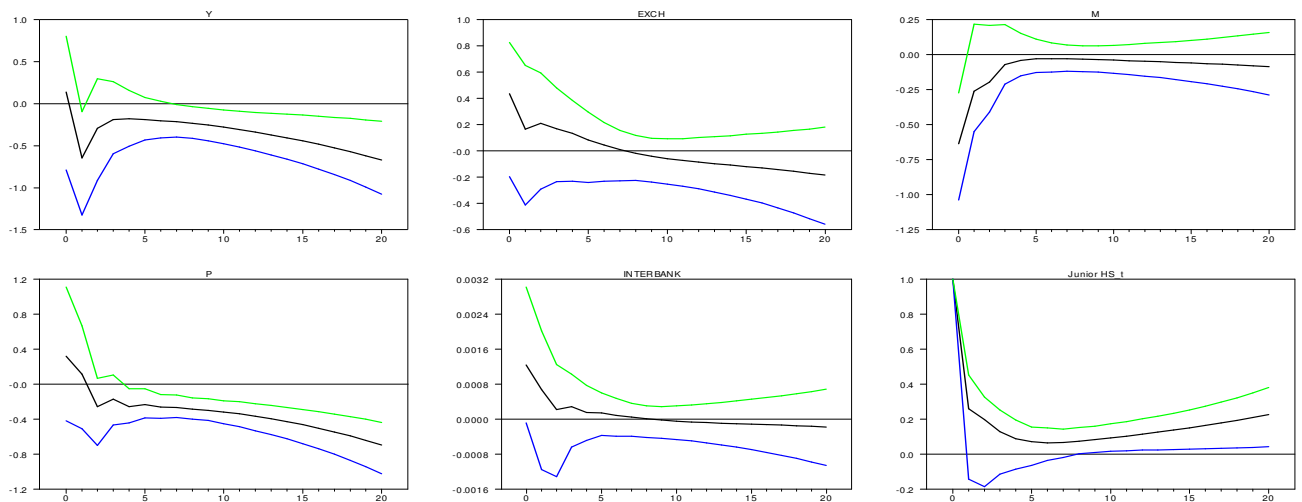

B: On Female Junior High School Unemployment

Effects of Shocks on Junior HS_f
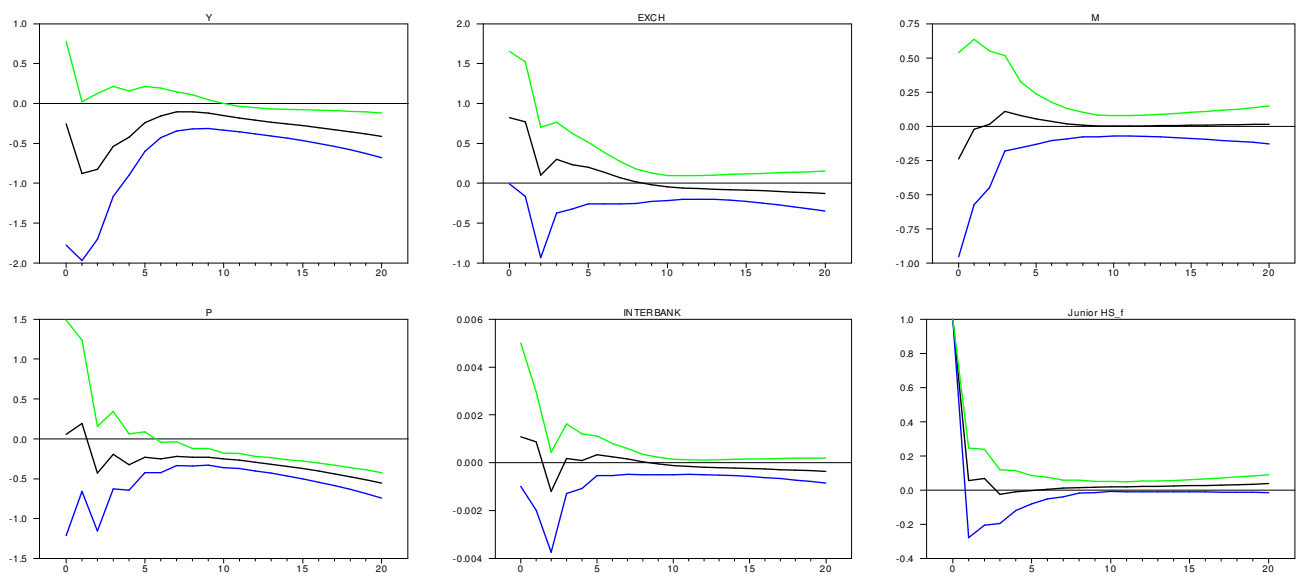

C: On Male Junior High School Unemployment

Effects of Shocks on Junior HS_m
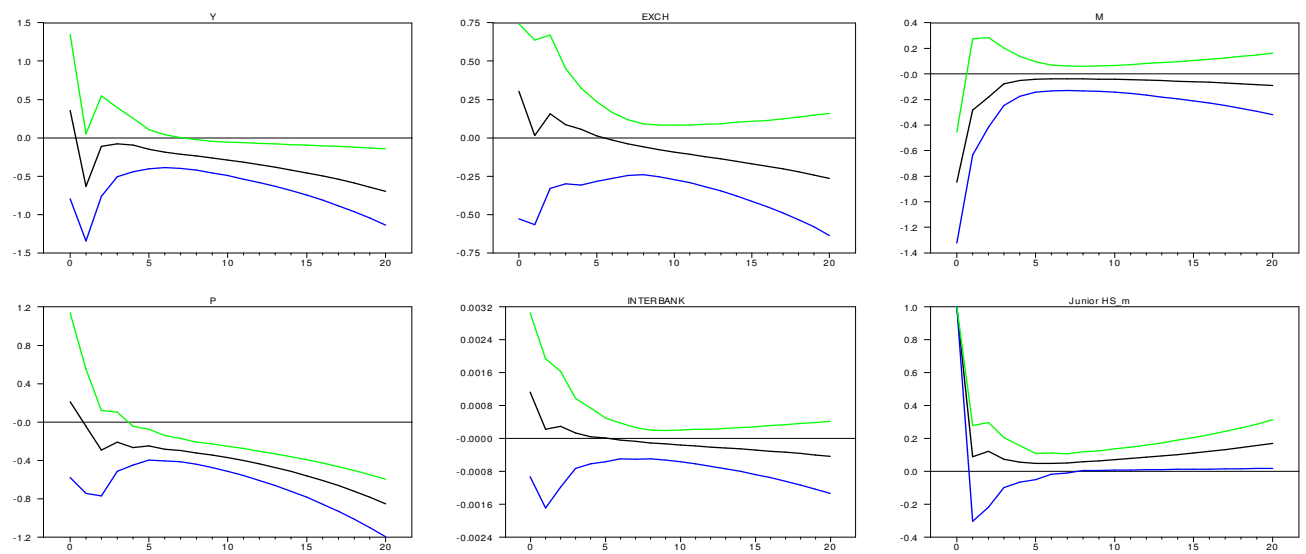
Figure 10: Responses of Vocational School at High School Level Unemployment to Economic Shocks

A: On Total Vocational School at High School Level Unemployment

Effects of Shocks on Voc.HSLevel_t
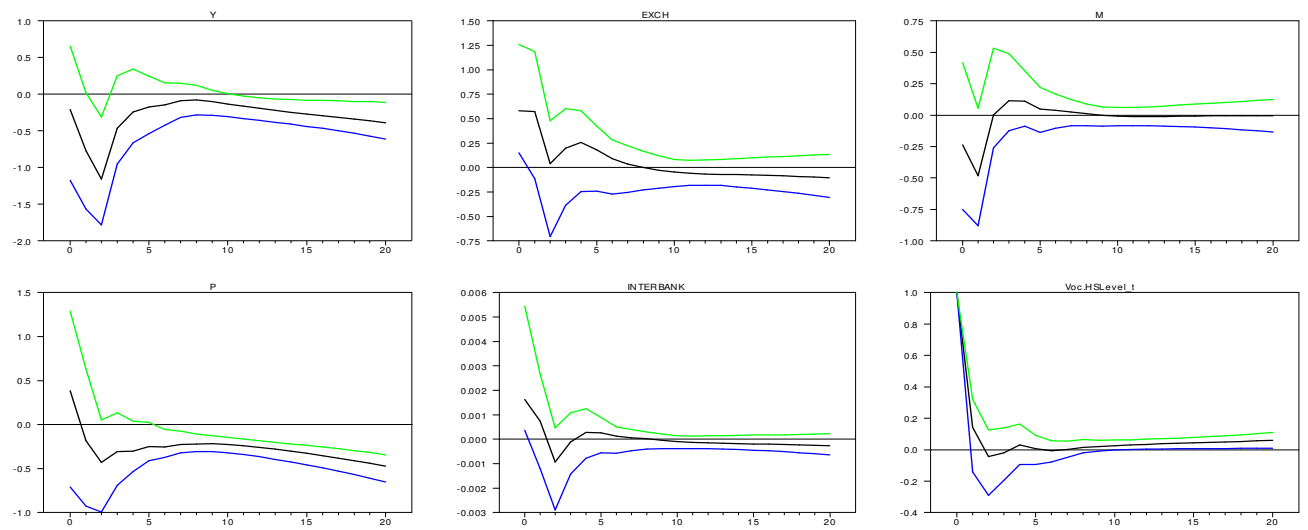

B: On Female Vocational School at High School Level Unemployment

Effects of Shocks on Voc.HSLevel_f
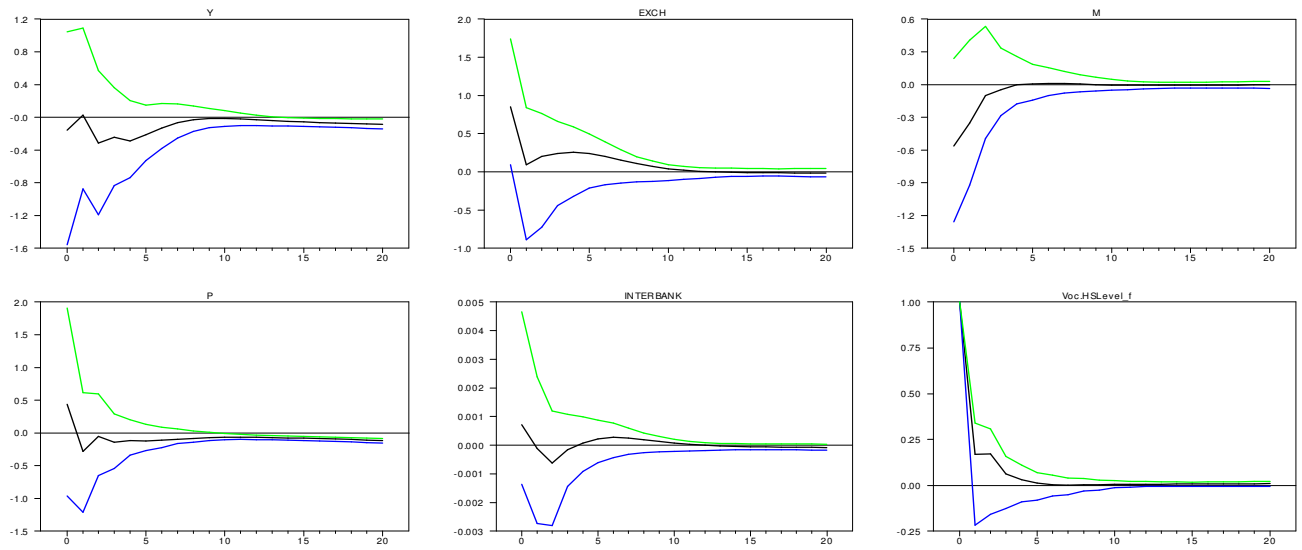

C: On Male Vocational School at High School Level Unemployment

Effects of Shocks on Voc.HSLevel_m
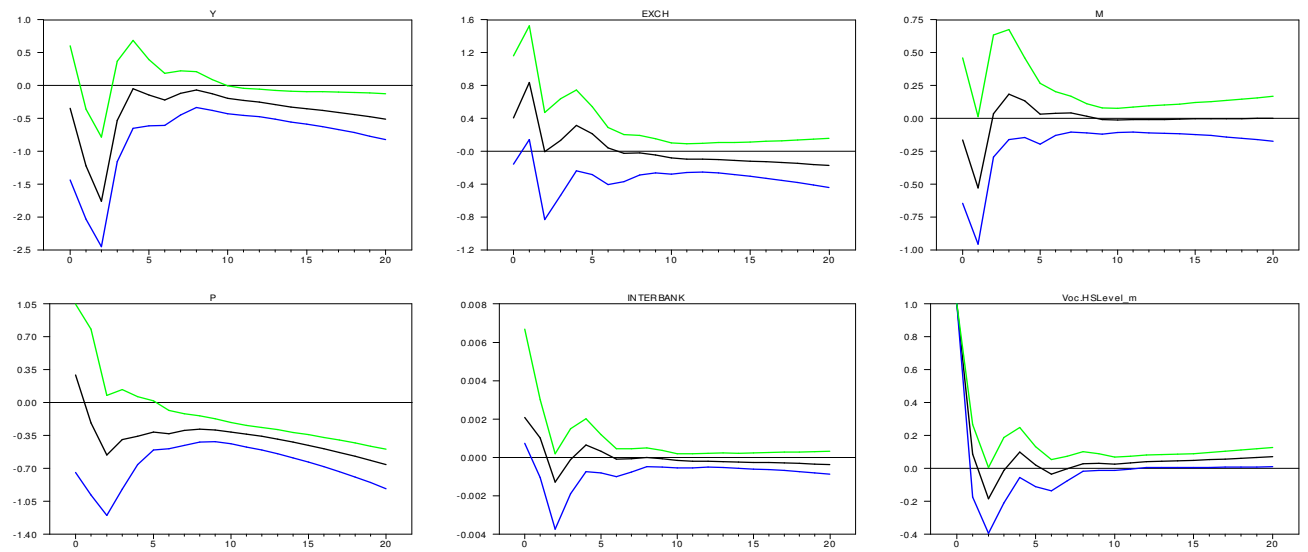
Figure 11: Responses of High School Unemployment to Economic Shocks A: On Total High School Unemployment

Effects of Shocks on High School_t
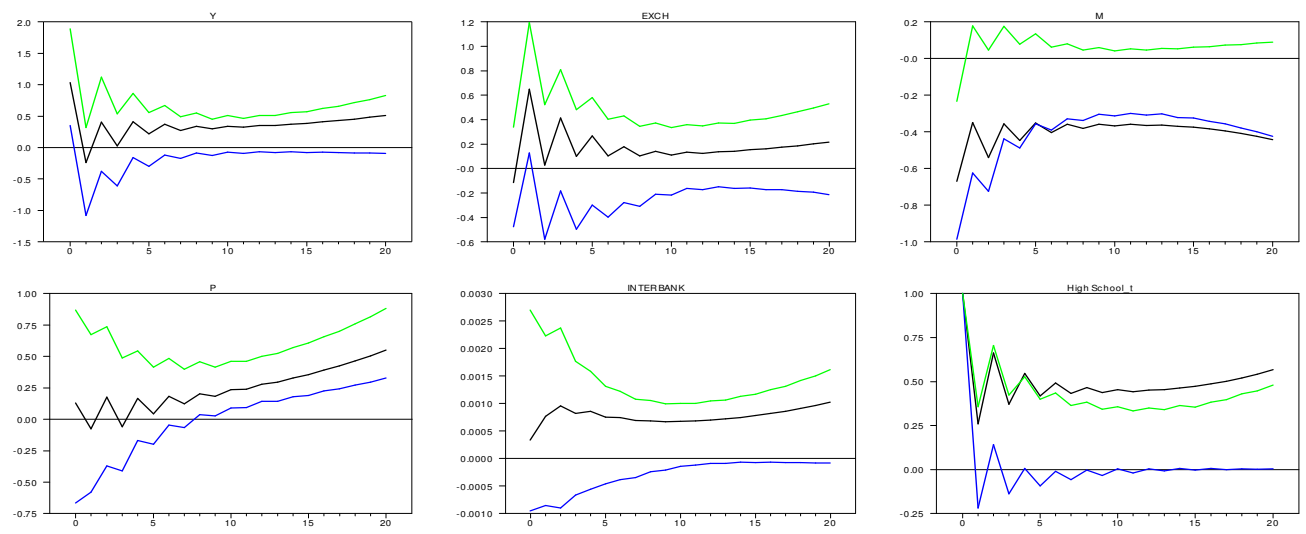

\section{B: On Female High School Unemployment}

Effects of Shocks on High School_f
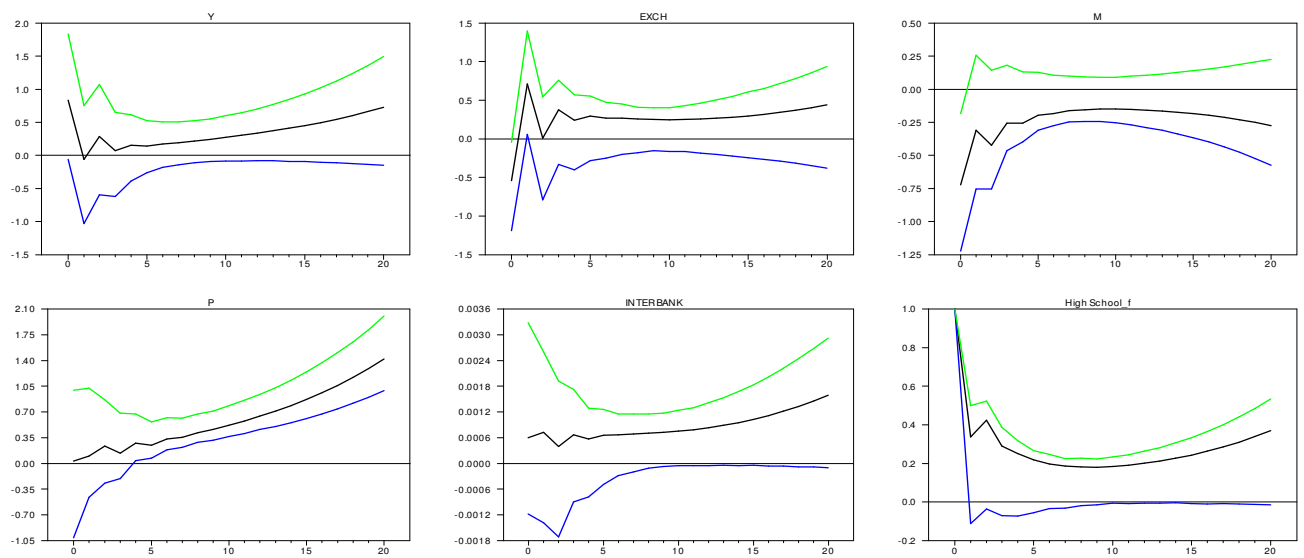

\section{C: On Male High School Unemployment}

Effects of Shocks on High School_m
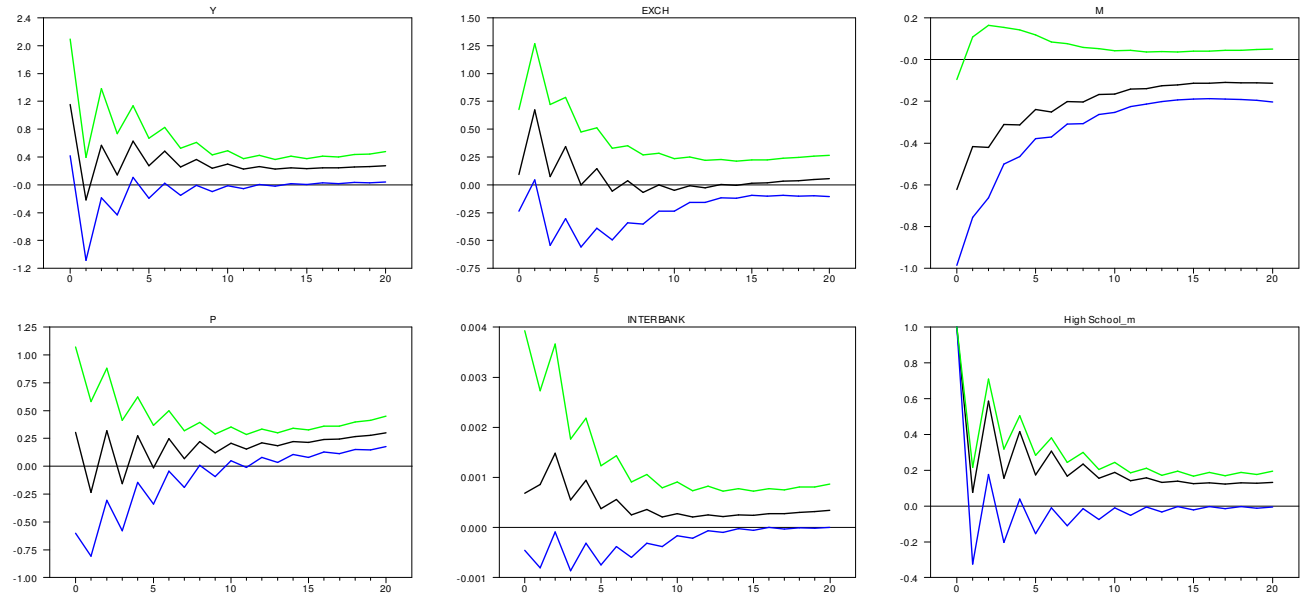
Figure 12: Responses of Higher Education Unemployment to Economic Shocks A: On Total Higher Education Unemployment

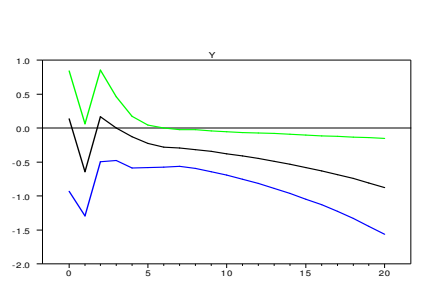

Effects of Shocks on Higher Edu_t
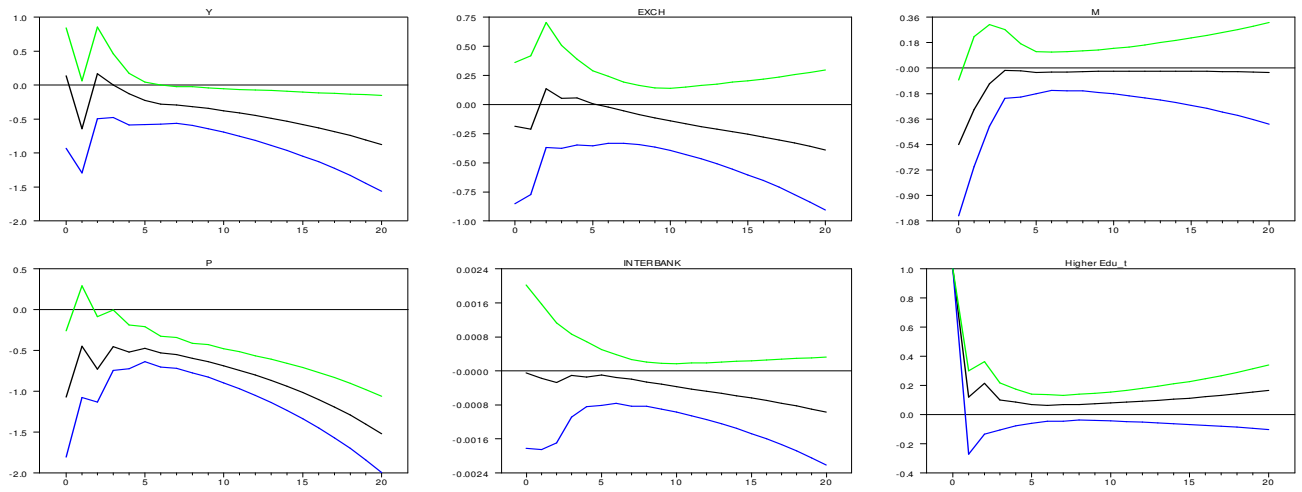

B: On Female Higher Education Unemployment

Effects of Shocks on Higher Edu_f
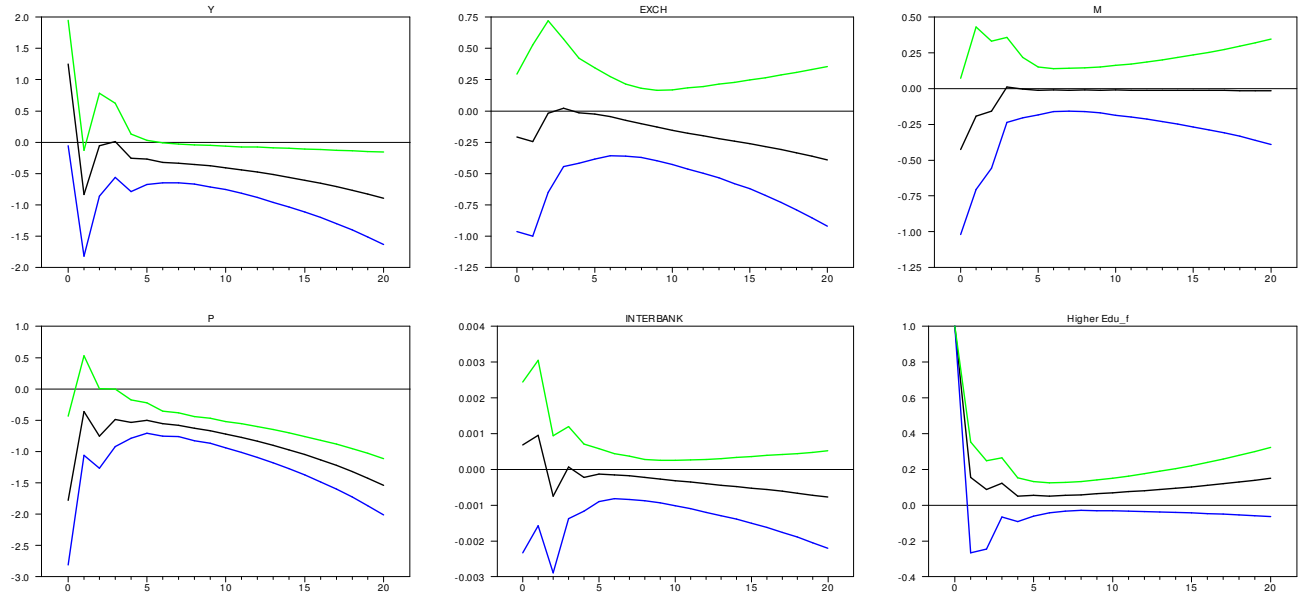

\section{C: On Male Higher Education Unemployment}

Effects of Shocks on Higher Edu_m
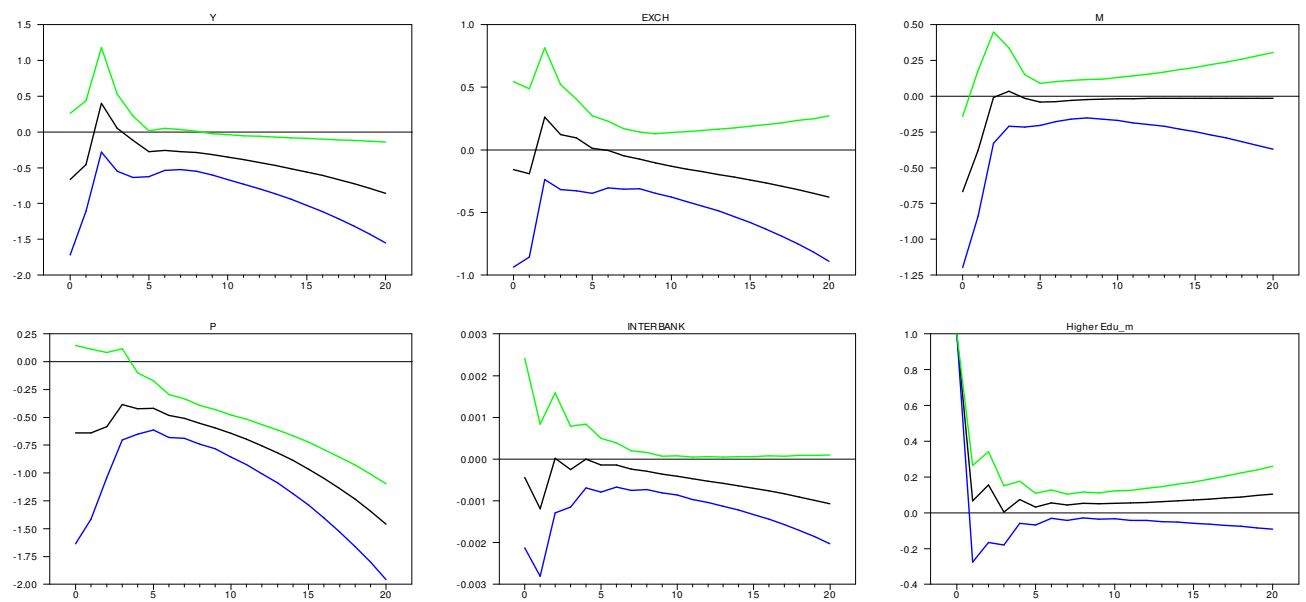